\title{
Problems Of Copyright Protection: Plagiary And Piracy On The Internet
}

\author{
${ }^{1}$ Yakubova Iroda Bakhramovna, ${ }^{2}$ Yakubov Aybek Bakhramovich \\ ${ }^{1} \mathrm{PhD}$ (Doctor of Philosophy), \\ Acting Associate Professor of Tashkent State University of Law, \\ ${ }^{2}$ Independent researcher of Tashkent State University of Law \\ Tashkent, Uzbekistan. \\ Sayilgoh street,34. +9989001771510
}

Article History:Received:11 January 2021; Accepted: 27 February 2021; Published online: 5 April 2021

\begin{abstract}
The main purpose of this article is to study the institution of copyright protection, with the division of powers of collective management organizations, with the functions of organizations and their types, with the difference between collective management of copyright and such a concept as representation are touched upon. The main focus is on the main goals of improving the judicial system in accordance with the Uzbekistan's Five-Area Development Strategy for 2017-2021 in general and proposals for further improvement of the legislation were formed on the basis of the approach, proposed by the author. Also, attention is paid to some urgent problems related to the improvement of this institution, international standards for copyright protection and comparative legal analysis of national legislation, as well as the opinions of scientists from Uzbekistan and other different countries. Suggestions and recommendations were put forward of scientific and practical importance for national copyright law.
\end{abstract}

Key words: copyright, to enforce copyright, royalty, copyright and related rights collective management, public performance or display of a work, civil law protection, respect the rights, individual rights, inalienable rights.

\section{Introduction:}

With the advent of new technologies, an area in which the individual exercise of the rights of authors and related rights holders is impossible or at least impractical is constantly and rapidly evolving, and collective management of copyright and related rights is becoming more and more important, the most efficient and internationally recognized. the way of exercising these rights in the context of extremely rapid development of technology and technology. Why is collective management necessary and on what principles should it be built? Copyright law assigns to the author of a work the exclusive right to use a work in any form and in any way, defines in an exhaustive manner the permitted limitations of this right, and also provides for a mechanism for its implementation, calling a contract a means of granting the right to use a work to others and establishing requirements for what this contract should be. If a work is protected by copyright, then you can get the opportunity to use it by concluding an agreement with the author or his assignee. Similar rules apply to objects of related rights.

However, in many cases such a scheme cannot be implemented in practice. In this case, we are talking about the absence of not a legal, but an actual opportunity, since some organizations, due to the nature of their activities, cannot conclude an agreement with the author (rightholder) of each used work (performance, phonogram) only because there are too many of these works, and rightholders, in turn, cannot do this, because their works or objects of related rights are used by a large number of users. The solution to the problem is the creation of specialized organizations that simultaneously represent the interests of a large number of rightholders in relations with persons using their works (objects of related rights), i.e. collective management organizations.

The essence of collective management is that the organizations involved in it conclude agreements with authors and other rightholders, under which they assume obligations to manage these rights; on the basis of the powers granted by the rightholders, collective management organizations, on their own behalf, conclude contracts with persons using the works (objects of related rights); collect, distribute and pay remuneration to copyright holders; protect the rights of authors and other rightholders in court; some organizations also perform social support functions for their members. At the same time, the characteristic "collective" is intended to emphasize that management is carried out simultaneously and on general terms by the rights of a large number of rightholders.

\section{METHOD AND MATERIALS:}

The study of civil law protection of the copyrights was conducted using comparative legal, historical and system-structural. Thus, the historical approach was used to cover the historical aspects of the emergence 
and formation of personal rights in foreign countries. Comparison of the experience of international states and Uzbekistan regarding the civil law protection of the copyrights was carried out using the comparative legal method. An analysis of the latest scientific publications devoted to the study of plagiary and piracy on the internet, generalization and presentation of the results of the study allowed system structural method.

In the context of the active expansion of international trade and globalization, issues related to intellectual property are at the forefront of discussions and debates. A person wants the product of his mental and physical labor to appear, to be presented to the public, so that people can use it. But in this case, violation of rights, of course, causes moral and material damage to the creator. It is no secret that the penetration of the Internet into the general public, where the opportunity arose to show their creativity, also opened up illegal ways for plagiarism to use other people's labor. So, copyright is one of the pressing issues of our time. Chapter 60 of the Civil Code of the Republic of Uzbekistan defines the foundations of copyright law. In addition, the Law of the Republic of Uzbekistan "On Copyright and Related Rights" protects copyright in our country.

By the end of the 19th century, when the products of intellectual activity became a determining factor in development, an international scientific and technical market appeared, and an objective need arose to harmonize the laws regulating this area in different countries [O.Okyulov]. In the modern world, copyright protection has become a problem in some places, along with the discovery of artificial intelligence [I.Yakubova] by artists and inventors in various fields, especially its implementation in modern life. In order to continue the ongoing reforms to improve the intellectual property sector in the country, increase the investment attractiveness of the country, the Republic of Uzbekistan and the accession of the Republic of Uzbekistan to the Treaty on Phonograms (Geneva, December 20, 1996). These international agreements are a recognition of Uzbekistan's clear and unambiguous compliance with international requirements in the field of intellectual property, copyright and related rights and are aimed at protecting the rights of authors of literary and artistic works, performers and their reproduction of phonograms.

\section{RESULTS AND DISCUSSION}

The legal basis for copyright protection in our national legislation is set out in the Law of the Republic of Uzbekistan "On Copyright and Related Rights". regulation of relations arising in connection with the creation and use of broadcasts (related rights). Pursuant to article 11 of this law, the owner of absolute copyright can use the copyright protection mark to communicate his rights. Currently, the most common copyright infringement cases are associated with Internet networks. Users of the global network are mainly divided into two camps: some are looking for information, entertainment and services, while others provide this information, entertainment and services [A.Yuldashev].

As for the norms governing all processes on the Internet, they do not exist today. It is noted that no country has laws regulating legal relations in the global network, which creates a very wide range of opportunities for users to control, copy and further distribute objects protected by copyright without control. It is almost impossible to restrict the global Internet, even by law: as a result, copyright infringement on the Internet is a common occurrence, with which it is very difficult, and sometimes useless, to deal with.

In accordance with Article 65 of the Law on Copyright and Related Rights [6], there are the following methods of copyright protection: recognition of rights as a means of protecting copyright and related rights; restore the situation before the violation and stop actions that violate the law or create a threat of its violation; in the event that the rights of the copyright holder are not violated, he has the right to compensation for losses in the amount of income that he could have received under normal conditions of civil proceedings, but did not receive; if the infringer received income as a result of violation of copyright or related rights, the copyright holders, among other things, compensate for the lost profit in the amount of at least such income; pay compensation for damage, as well as take other measures provided by law. In addition to these methods of protection, the infringer of copyright also has the right to demand moral damage from the infringer [Sh.Khujayev]. In addition, an organization that administers property rights on a collective basis has the right to go to court on its own behalf in the manner prescribed by law to protect the violated copyright and related rights of individuals.

Despite these grounds for protection, the absence of judicial practice on copyright infringement on the Internet (and, accordingly, the absence of such laws) is due to certain reasons: the authors' fear to sue to protect their rights; lack of the ability to collect evidence and correctly record the evidence base; insufficient technical and legal literacy of the population; insufficient qualifications of lawyers in the field of Internet technologies.

Thus, one of the legal issues in the regulation of the Internet industry is the problem of copyright protection, since user behavior on the Internet often affects the rights of authors and their heirs. Daily activities such as browsing the web, storing them in the computer's memory, copying texts, copyright protected images, sound alarms, unlimited access to them for users. The most common problem related to copyright infringement on the Internet is plagiarism. Based on this, it can also be difficult for us to distinguish between authors-authors 
of science, literature or art, video or other works. It is much easier for a consumer to copy other people's summer texts than to create something unique and attractive [B.Mukumov].

Today, not a single country has laws regulating legal relations in global networks, which provide users with a very wide range of opportunities for uncontrolled copying, copying and further distribution of legal entities. Legislation can hardly limit the scope of the Internet. Thousands of crimes (libel, extremist activity, etc.) are committed on the Internet today.

As for online copyright infringement, they are practically indistinguishable from offenses outside of virtual life: plagiarism, illegal distribution of copyrighted information, and so on. Plagiarism is the deliberate transfer of copyright to another person's literary, artistic or scientific work, a deliberate act that entails civil or even criminal liability. Plagiarism often finds expression in connection of copyright with the results of intellectual activity of other people, publishing them under their own names. Plagiarism is the use of someone's work, partially or without reference to the source.

There is no need to publish a work created on the basis of plagiarism, it is enough to find it in any objective form, for example, in the form of a manuscript or as part of another work. The main and inherent feature of plagiarism is the legal consequence of the assignment of copyright to this work. Although the concept of plagiarism is very clear, its content remains unclear. Indeed, plagiarism is not always indistinguishable from other similar concepts. Thus, acts of illegal use, copying and publication of copyrighted material by others are not always plagiarism. This illegal behavior is another type of copyright infringement, often referred to as "piracy". Such actions can only be considered plagiarism if they are copyrighted to those copied or stolen works or materials.

It may not be plagiarism when the author uses a specific plot, topic of work or scientific idea in any other way. The similarity of some ideas to each other is also not considered plagiarism, since authors can often implement similar results of creation on an independent basis without knowing about each other's products.

\section{CONCLUSION:}

Plagiarism should include a certain type of design, an individual form of a new work, an external original shell, the use of which is called "plagiarism". In practice, there is also so-called "involuntary" plagiarism, which means the publication or other distribution of the same work with the same title and content to someone else's work, as well as a work that is mistakenly considered their own personal work, not knowing about the existence author's and Self-control and disposition also fall into the category of involuntary plagiarism. Most often, such works are found in artistic and musical works of students.

In many cases, most copyright owners find it difficult to clarify their legal position in court and gather the necessary evidence. According to Uzbek law, each party must prove the circumstances of the dispute in court, so the main task of the author is to collect evidence of copyright infringement in the industry.

In recent years, "piracy" has become widespread. Electronic documents, books, articles are copied, often changed without the consent of the author, there are cases of direct ownership of works for which the author is not directly indicated. Lack of information about the author (s) of the work does not mean that unauthorized use of these works, piracy, as well as plagiarism [M.Bakhramova] is allowed, and also does not mean that illegal copyright holders are not exempt from liability.

In conclusion, the rapid development of science and technology is impossible without the legal strengthening of the protection of intellectual property rights.

To protect your copyrights on the Internet, the author should pay attention to the following: understand that they own copyrights and know how to exercise their rights; know how to properly use the legal assistance of qualified professionals who can help authors; The copyright owner should understand that the worldwide piracy rate is very high, sometimes the author does not have to upload the entire work of authorship to the world's websites.

Conscientiousness is also important in exercising the copyright owner's rights in a work when using the work. From the study, we can conclude that currently there are insufficient effective ways to protect civil rights to works of science, literature and art on the Internet, and there are more cases of circumvention of the law than compliance with copyright law. It is much more difficult to manage and regulate the processes taking place on the Internet, which is mainly related to the extraterritorial factors of the Internet. However, the copyright owner can protect his rights by properly applying copyright protection methods in the law.

Although changes and additions to Uzbek legislation in recent years have eliminated some shortcomings and gaps, copyright still needs to be improved, including the introduction of new rules for the protection of intellectual property on the Internet. The development of science and technology cannot take place without the legal strengthening of copyright.

Therefore, we believe that the first effective way to combat Internet piracy is education, i.e. its essence is to educate society and individuals in the spirit of respect for intellectual property, and not abuse someone else's intellectual property, and the second method is propaganda through the media. should cover areas such as 
conducting comprehensive PR campaigns, promoting the legitimate use of licensed products, stopping the illegal use of intellectual property on the Internet and its theft. The next method is to strengthen administrative or criminal sanctions against illegal distributors (manufacturers) on the Internet. In particular, the high level of criminal sanctions for violations in this regard in countries such as the USA, Japan, France, the Netherlands, Denmark, Sweden, also testifies to the effectiveness of this area.

In addition to protecting copyright and related rights on the Internet, collecting and distributing royalties (royalties) of performers, ensuring compliance with applicable rules when concluding copyright agreements, increasing liability for violations of copyright and related rights, and a number of other areas. a number of issues, such as the ratification of international treaties, remain relevant. Finding a delicate balance between the interests of rights holders, their users and intermediaries is a key challenge for the international community.

\section{REFERENCES:}

1. O.Okyulov. Intellectual property law. // Institute of philosophy and law named after I.M. Mminov. Tashkent, 2005, - C-9.

2. Yuldashov A. A. Government policies related to social protection of disabled persons in Uzbekistan: national and international aspects (https://www.researchgate.net/publication/330723898_Government_policies_related_to_s ocial_protection_of_disabled_persons_in_uzbekistan_national_and_international_aspects)

3. Yakubova I., Satvaldieva Y. Comparative legal analysis civil-law protection of honor, dignity and business reputation in the civil legislation of Uzbekistan and Japan //European Journal of Molecular \& Clinical Medicine. - 2020. - T. 7. - №. 2. - C. 584-594.

4. Bakhramova Mokhinur A thorough review of the common law concept of "arbitrary termination" and "unfair dismissal" (including DIFC\&ADGM // Review of law sciences. 2020. № November Exclusive issue. URL: https://cyberleninka.ru/article/n/a-thoroughreview-of-the-common-lawconcept-of-arbitrary-termination-and-unfair-dismissalincluding-difc-adgm (дата обращения: 10.02.2021).

5. Khujayev, S. A. (2018). Judgments under the Law of the Republic of Uzbekistan «On banks and bank activity» in the new edition. International Journal of Legal Studies (IJOLS), 4(2), 295-301.

6. Мукумов Б. Оценка регулирующего воздействия нормативноправовых актов на предпринимательскую деятельность в условиях пандемии коронавируса (на примере Торгово-промышленной палаты Республики Узбекистан) // Review of law sciences. 2020. №2. URL: https://cyberleninka.ru/article/n/otsenka-reguliruyuschegovozdeystviyanormativno-pravovyh-aktov-na-predprinimatelskuyu-deyatelnost-vusloviyahpandemii (дата обращения: 10.02.2021).

7. Buzanov V. Yu. Copyright: the saga of timing // Journal of Russian law. 2014. No. 6. P. 73-81.

8. Gavrilov EP Originality as a criterion for the protection of objects by copyright // Russian Library of Intellectual Property; URL: http://www.rbis.su/article.php?article=434 (date of access: 03/23/2017).

9. Sitdikova RI Conscientiousness in the protection of personal copyright // Laws of Russia. 2010. No. 9. P. 42-46.

10. Baimoldina Svetlana Malikovna. Concept of legal protection of intellectual property rights // Procedia - Social and Behavioral Sciences 176 (2015) 998 - 1004

11. Gaetano Dimita. Copyright and Shared Networking Technologies // A Thesis Submitted for the Degree of Doctor of Philosophy Queen Mary, University of London 2010

12. Dvoryankin OA Protection of copyright and related rights. Responsibility for their violation. Criminal law aspect. // Scientific and practical guide. 2002. 